\title{
Effects of Quinine, Quinidine and Chloroquine on Human Muscle Nicotinic Acetylcholine Receptors
}

\author{
Günter Gisselmann ${ }^{1 *}$, Desiree Alisch ${ }^{1}$, Brigitte Welbers-Joop ${ }^{2}$ and Hanns Hatt ${ }^{1 *}$ \\ ${ }^{1}$ Department of Cell Physiology, Ruhr-University-Bochum, Bochum, Germany, ${ }^{2}$ Cassella-med GmbH \& Co. KG, Koeln, \\ Germany
}

The genus Cinchona is known for a range of alkaloids, such as quinine, quinidine, cinchonine, and cinchonidine. Cinchona bark has been used as an antimalarial agent for more than 400 years. Quinine was first isolated in 1820 and is still acknowledged in the therapy of chloroquine-resistant falciparum malaria; in lower dosage quinine has been used as treatment for leg cramps since the 1940s. Here we report the effects of the quinoline derivatives quinine, quinidine, and chloroquine on human adult and fetal muscle nicotinic acetylcholine receptors (nAChRs). It could be demonstrated that the compounds blocked acetylcholine (ACh)-evoked responses in Xenopus laevis oocytes expressing the adult nAChR composed of $\alpha \beta \varepsilon \delta$ subunits in a concentrationdependent manner, with a ranked potency of quinine $\left(\mathrm{IC}_{50}=1.70 \mu \mathrm{M}\right)$, chloroquine $\left(\mathrm{IC}_{50}=2.22 \mu \mathrm{M}\right)$ and quinidine $\left(\mathrm{IC}_{50}=3.96 \mu \mathrm{M}\right)$. At the fetal $\mathrm{nAChR}$ composed of $\alpha \beta \gamma \delta$ subunits, the $\mathrm{IC}_{50}$ for quinine was found to be $2.30 \mu \mathrm{M}$. The efficacy of the block by quinine was independent of the ACh concentration. Therefore, quinine is proposed to inhibit ACh-evoked currents in a non-competitive manner. The present results add to the pharmacological characterization of muscle nAChRs and indicate that quinine is effective at the muscular nAChRs close to therapeutic blood concentrations required for the therapy and prophylaxis of nocturnal leg cramps, suggesting that the clinically proven efficacy of quinine could be based on targeting nAChRs.

Keywords: quinine, nocturnal leg cramps, nicotinic acetylcholine receptor, two-electrode voltage clamp, ion channel block

\section{INTRODUCTION}

Quinoline derivatives such as natural quinine, quinidine, and synthetically produced chloroquine are well known for their use in the treatment of malaria (Figure 1). The efficacy of quinine against nocturnal leg cramps has been proven in randomized clinical trials (Diener et al., 2002; El-Tawil et al., 2015). But the muscle relaxant mechanism of action of quinine has not been fully elucidated yet. As it does not freely cross the blood brain barrier (Silamut et al., 1985), quinine is supposed to be a peripheral muscle relaxant in vivo. In higher dosage as used against malaria, central nervous effects may occur. Quinine and its derivatives are acting on a variety of ion channels including several types of potassium channels (Glavinović and Trifaró, 1988; Imai et al., 1999), members of family of ligand-gated ion channels such as the 5-HT3-type of serotonin receptor (Thompson et al., 2007; Thompson and Lummis, 2008) and nicotinic acetylcholine receptors (nAChR) 
(Fukudome et al., 1998b; Ballestero et al., 2005). Quinine's significant bitterness, widely enjoyed in tonic bitter lemonades, is attributed to activation of bitter taste receptors (T2Rs) which are not limited to taste buds but are expressed in many extraoral tissues (Upadhyaya et al., 2016). Further, quinolines influence cholinergic synaptic transmission (Sieb et al., 1996). This effect is possibly the basis for their use in further applications like the treatment of muscle cramps (Katzberg, 2015) and slow channel congenital myasthenic syndrome (SCCMS) (Harper and Engel, 1998; Harper et al., 2003; Peyer et al., 2013).

It is known that quinine acts on muscular and neuronal nAChRs (Sieb et al., 1996; Fukudome et al., 1998a,b; Ballestero et al., 2005). However, the interaction of quinine has also been reported for receptors present at the neuromuscular junction, in which it produces long-lived open-channel as well as a closed-channel block and can normalize the open duration of channel events in the slow-channel congenital myasthenic syndrome (Sieb et al., 1996; Fukudome et al., 1998a,b). Slow channel congenital myasthenic syndrome (SCCMS) is caused by missense mutations in subunits of nicotinic acetylcholine receptor (AChR) at the neuromuscular junction (Engel, 2018). Mutated AChR channel produces prolonged opening events leading to a depolarization block and endplate myopathy. Quinoline derivatives such as quinidine correct the prolonged opening times of the mutated acetylcholine receptor channels in myasthenic syndrome (Bleecker et al., 1998). On the contrary, in myasthenia gravis quinine is contraindicated because it decreases the excitability of the motor end-plate region, thereby reducing responses to repetitive nerve stimulation by acetylcholine. These may be the underlying effects explaining the use of low dose quinine in the therapy and prophylaxis of leg cramps.

Quinine is also blocker for the neuronal $\alpha 9 \alpha 10$ nAChRs. At this cochlear type of ACh receptor, a mixed competitive and non-competitive inhibition was observed (Ballestero et al., 2005). nAChRs form together with 5-HT3-, GABA(A)-, and glycine receptors the superfamily of ligand-gated ion channels (Albuquerque et al., 2009). Possibly due the strong structural and functional similarities between these receptors, quinine is also a blocker of 5-HT3- and at elevated concentrations also of GABA(A) receptors (Thompson and Lummis, 2008).

The composition of muscle nAChRs is dependent of the developmental stage. The fetal $\mathrm{nAChR}$ together with the receptor in denervated muscles is composed of $\alpha \beta \gamma \delta$ subunits with a stoichiometry of $(\alpha 1)_{2} \beta_{1} \gamma \delta$. In the adult, $\gamma$ is replaced by the $\varepsilon$ subunit (Kalamida et al., 2007). In our present study, we examined the effects of the quinoline derivatives quinine, quinidine, and chloroquine on adult and fetal human muscle nAChRs recombinantly expressed in $X$. laevis oocytes and provide evidence that these compounds block the nAChRs.

\section{MATERIALS AND METHODS}

\section{Expression System}

The expression plasmids contain the cDNA coding for the different human nAChR subunits in pRBG4 (Ohno et al., 1996). Cloned muscular AChR subunit cDNAs were kindly provided by Dr A. G. Engel (Mayo Clinic, Rochester, MN, United States) and Dr. F. Grassi (Carattere Scientifico San Raffaele Pisana, Rome, Italy). Cloned cDNA of the human a7 AChR subunit was described by Schreiner et al. (2014). cRNAs were prepared using the AmpliCap T3 high-yield message marker kit (Epicenter, Madison, WI, United States), following the manufacturer's protocol. Oocytes were obtained as previously described (Gisselmann et al., 2004) and injected with a total amount of $\sim 30 \mathrm{ng}$ of a mixture of the receptor-coding cRNA using an injection-setup from WPI (Nanoliter 2000, Micro4). For the muscular type, a mixture of cRNAs for $\alpha, \beta, \delta$, and $\varepsilon$ in a stoichiometry of 2:1:1:1 was used and for the fetal type, $\varepsilon$ was replaced by $\gamma$. The injected oocytes were stored in ND 96 (96.0 mM NaCl, $2.0 \mathrm{mM} \mathrm{KCl}, 1.8 \mathrm{mM} \mathrm{CaCl}_{2}, 1.0 \mathrm{mM} \mathrm{MgCl} 2$, $5.0 \mathrm{mM}$ HEPES, pH 7.2, $200 \mathrm{U} / \mathrm{ml}$ penicillin, and $200 \mu \mathrm{g} / \mathrm{ml}$ streptomycin) at $12{ }^{\circ} \mathrm{C}$. Measurements were performed 4-6 days after cRNA injection.

\section{Electrophysiology}

The electrophysiological recordings were performed using the two-electrode voltage clamp technique as previously described (Sergeeva et al., 2010). All of the measurements were performed in normal frog ringer (NFR) [115 mM NaCl, $2.5 \mathrm{mM} \mathrm{KCl,} 1.8 \mathrm{mM}$ $\mathrm{CaCl}_{2}, 10$ mM HEPES; pH $\left.7.2(\mathrm{NaOH} / \mathrm{HCl})\right]$. The currents were recorded at a holding potential of typically $-60 \mathrm{mV}$ using the Cell Works 6.1.1. software (NPI).

\section{Substances}

The chemicals were obtained from Sigma-Aldrich or Cassellamed GmbH \& Co. KG (quinine) and disssolved in NFR.

\section{Data Analysis}

In blocking experiments, the test substances were applied in an alternating manner with ACh. Therefore, the currents of the test substances or the modulated currents were normalized to the mean of the ACh-induced currents before and after the test substance was applied. The concentration-response data were fitted with the logistic equation using SigmaPlot 8.0 (SPSS). The deviations are represented by the standard error of the mean (SEM).

\section{RESULTS}

\section{Effect of Quinoline Derivatives on Adult Muscle nAChRs}

For the pharmacological characterization, we expressed the human muscle nAChRs recombinantly in $X$. laevis oocytes and characterized the ion channel activity using the twoelectrode voltage-clamp technique. In the first experiments, we established a concentration response curve for ACh on Xenopus oocytes expressing the adult $\mathrm{nAChR}$ composed of $\alpha \beta \gamma \varepsilon$ subunits (Figure 2). Under our experimental conditions, an $\mathrm{EC}_{50}$ value for $\mathrm{ACh}$ of $12.65 \pm 2.40 \mu \mathrm{M}, \mathrm{n}_{\mathrm{H}}=1.77 \pm 0.05(n=6)$ was determined, similar to the $\mathrm{EC}_{50}$ values previously reported in this expression system (Jonsson Fagerlund et al., 2009). Next, 


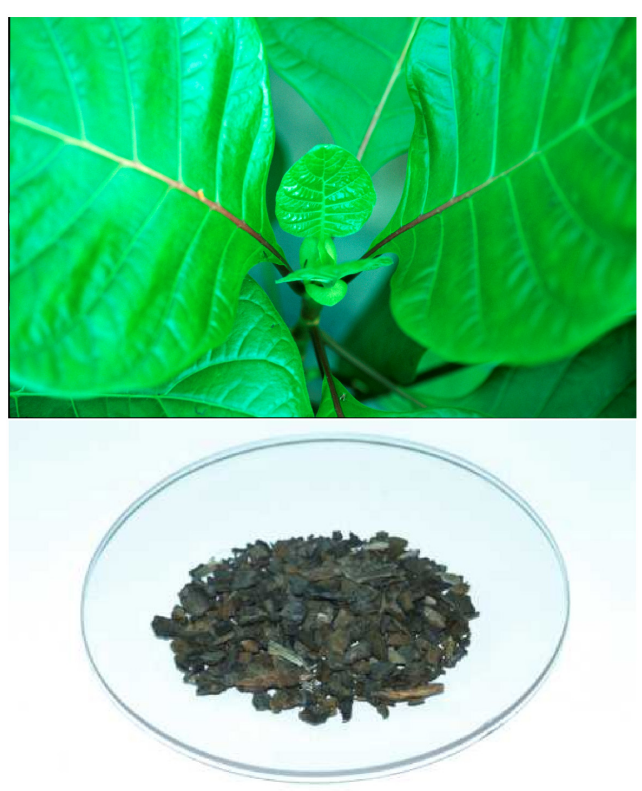<smiles>C=C[C@H]1CN2CC[C@H]1C[C@@]2(C)[C@H](O)c1ccnc2ccc(OC)cc12</smiles>

FIGURE 1 | Left: Cinchona calisaya and Cinchona bark as the source for quinine. Right: Molecular structures of quinine, quinidine, and chloroquine.

A

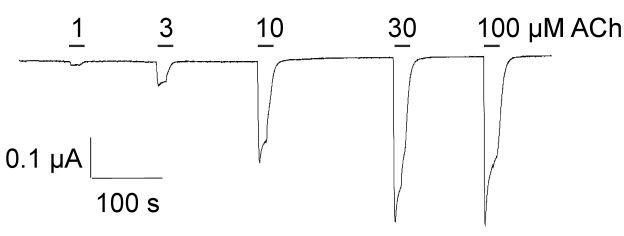

B

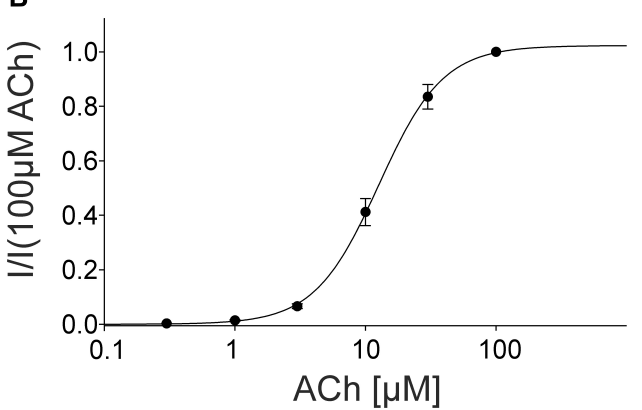

FIGURE 2 | Concentration-dependent activating effect of ACh on the adult human nicotinic acetylcholine receptor $\alpha \beta \varepsilon \delta$ measured in Xenopus oocytes. (A) Representative membrane currents evoked by ACh measured by two-electrode voltage-clamp. The mean current evoked by $10 \mu \mathrm{M}$ at the third application was 95\% +-. (B) Concentration-response curve of the receptor activated by different concentrations of acetylcholine $(n=6)$. Holding potential: $-60 \mathrm{mV}$, error bars represent S.E.M.

we tested the modulatory effects of quinoline derivatives on the response evoked by $10 \mu \mathrm{M}$ ACh, a near $\mathrm{EC}_{50}$ value of the agonist. All three tested quinoline derivatives blocked the AChevoked currents in a dose-dependent manner with a potency in the low $\mu \mathrm{M}$ range: quinine was most potent with an $\mathrm{IC}_{50}$ of $1.70 \pm 0.12 \mu \mathrm{M}(n=6)$ followed by chloroquine with an $\mathrm{IC}_{50}$ of $2.22 \pm 0.19 \mu \mathrm{M}(n=6)$. Quinidine was somehow less potent and blocked with an $\mathrm{IC}_{50}$ of $3.96 \pm 0.36 \mu \mathrm{M}(n=6)$ (Figure 3). The block by quinine was reversible, as shown in the Supplementary Figure 1A.

\section{Non-competitive Action of Quinine}

In the rat $\alpha 9 \alpha 10$ nAChRs, a mixed competitive / noncompetitive mode of antagonism for quinine was observed (Ballestero et al., 2005). To determine the mode of antagonism for quinine in the adult muscle nAChRs, we established concentration-response curves for $\mathrm{ACh}$ alone and for different concentrations of $\mathrm{ACh}$ in the presence of quinine at the same Xenopus oocyte. We used $1.8 \mu \mathrm{M}$ quinine which is a near $\mathrm{IC}_{50}$ concentration. In the case of a non-competitive mechanism, the inhibition should be independent of the ACh concentration, whereas the efficacy of competitive antagonists decreases with increasing ACh concentrations. The efficacy of quinine was independent of the ACh concentration (Figure 4A) and the determined $\mathrm{EC}_{50}$ of $\mathrm{ACh}$ didn't significantly change in the presence of $1.8 \mu \mathrm{M}$ quinine (Figure 4B). Further, also at elevated ACh concentrations, the maximally evoked current was never reached in the presence of $1.8 \mu \mathrm{M}$ quinine (Figure 4B).

For the rat $\alpha 9 \alpha 10 \mathrm{nAChRs}$ a slight voltage dependency of the quinine block was described indicating a potential binding site within or near the channel pore (Ballestero et al., 2005). We tested whether the quinine block of the muscular AChR was also voltage dependent and found that $1.8 \mu \mathrm{M}$ quinine blocked more pronounced at negative $\left(-60 \mathrm{mV}, \mathrm{I} / \mathrm{I}_{\max }=0.45 \pm 0.11\right.$, 
A
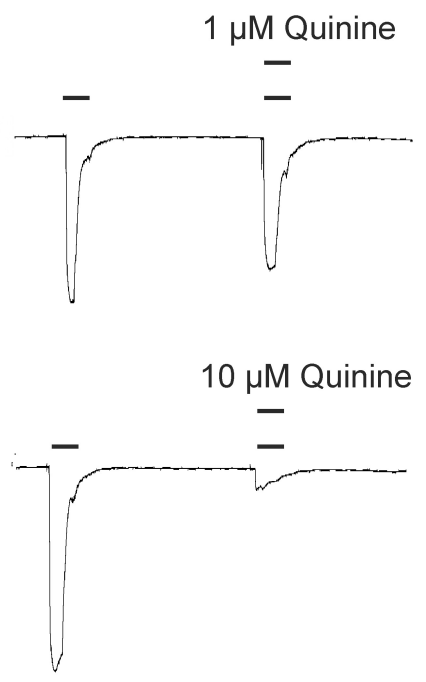

$3 \mu \mathrm{M}$ Quinine

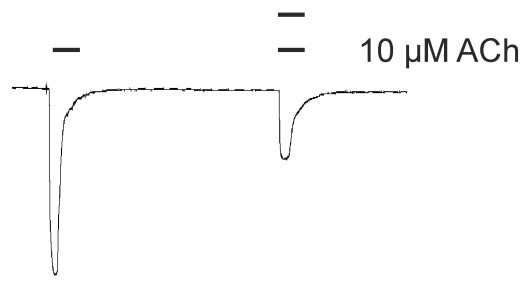

$30 \mu \mathrm{M}$ Quinine

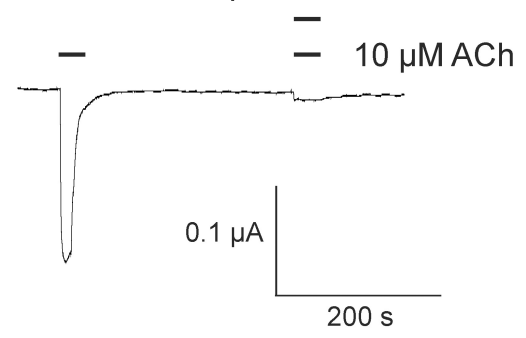

B

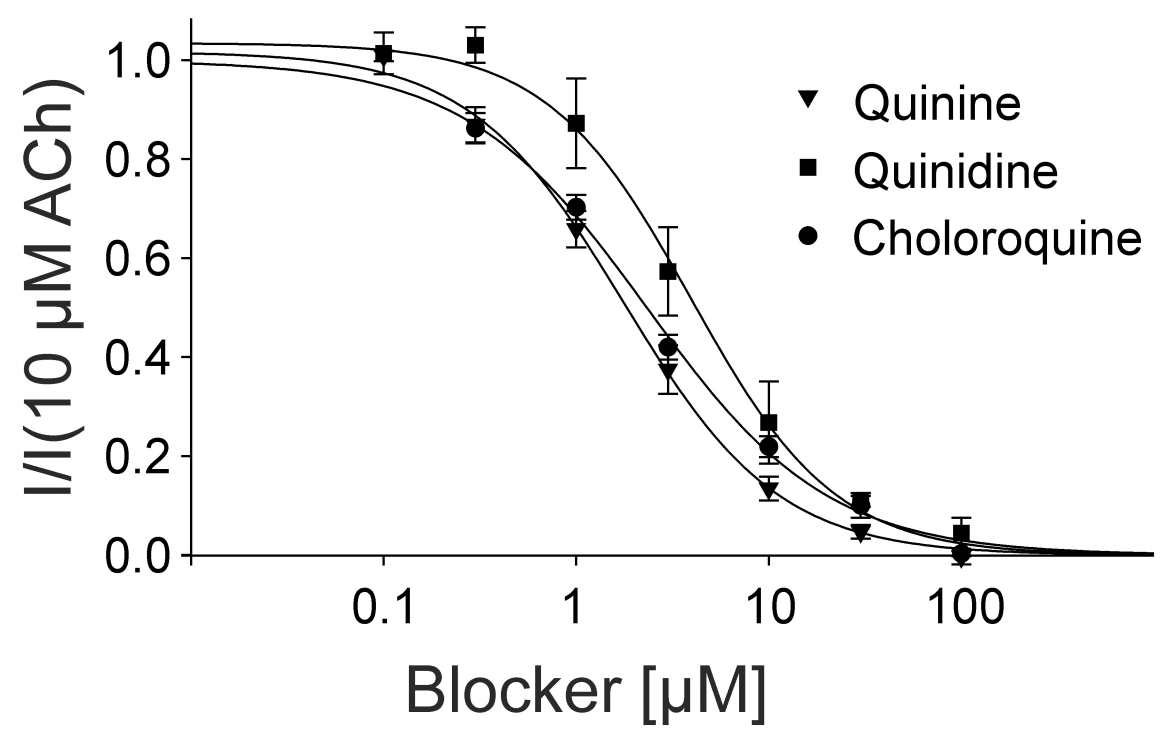

FIGURE 3 | Block of adult muscle nicotinic acetylcholine receptor by quinidine and derivatives in Xenopus oocytes. (A) Representative membrane currents measured by two-electrode voltage-clamp. Currents were elicited by $10 \mu \mathrm{M}$ ACh in presence of quinine. (B) Concentration-inhibition curves for quinine (inverted triangles), quinidine (squares), or chloroquine (circles) at ACh mediated currents elicited by $10 \mu \mathrm{M}$ ACh in the presence of different concentrations of the blockers $(n=6)$. Holding potential: $-60 \mathrm{mV}$, error bars represent S.E.M.

$n=3)$ than at positive membrane potentials $(++20 \mathrm{mV}$, $\mathrm{I} / \mathrm{I}_{\max }=0.87 \pm 0.07, n=3$ ) (Supplementary Figure 1C).

\section{Effect of Quinine on Fetal Muscle and Neuronal nAChRs}

For the pharmacological characterization, we expressed the fetal muscle nAChRs composed of $\alpha \beta \gamma \delta$ subunits recombinantly in $X$. laevis oocytes and characterized the ion channels using the two-electrode voltage-clamp technique. In the first experiments, we established a concentration response curve for ACh on Xenopus oocytes expressing fetal nAChRs (Figure 5). Under our experimental conditions, an $\mathrm{EC}_{50}$ value for $\mathrm{ACh}$ of $7.60 \pm 1.87 \mu \mathrm{M},(n=6)$ was determined, comparable for the $\mathrm{EC}_{50}$ reported for fetal receptors in the Xenopus oocyte system (Garland et al., 1998). Next, we tested the modulatory effects of quinine on the response evoked by $10 \mu \mathrm{M}$ ACh, a near $\mathrm{EC}_{50}$ value of the agonist, which blocked the ACh-evoked currents in a dose-dependent manner with an $\mathrm{IC}_{50}$ of $2.30 \pm 0.17 \mu \mathrm{M}(n=3)$ (Figure 4).

For the pharmacological characterization of neuronal receptor types, we expressed nAChRs composed of $\alpha 7$ subunits in $X$. laevis oocytes. Under our experimental conditions, the $\mathrm{EC}_{50}$ value for $\mathrm{ACh}$ was previously reported to be $90.5 \mu \mathrm{M}$ 

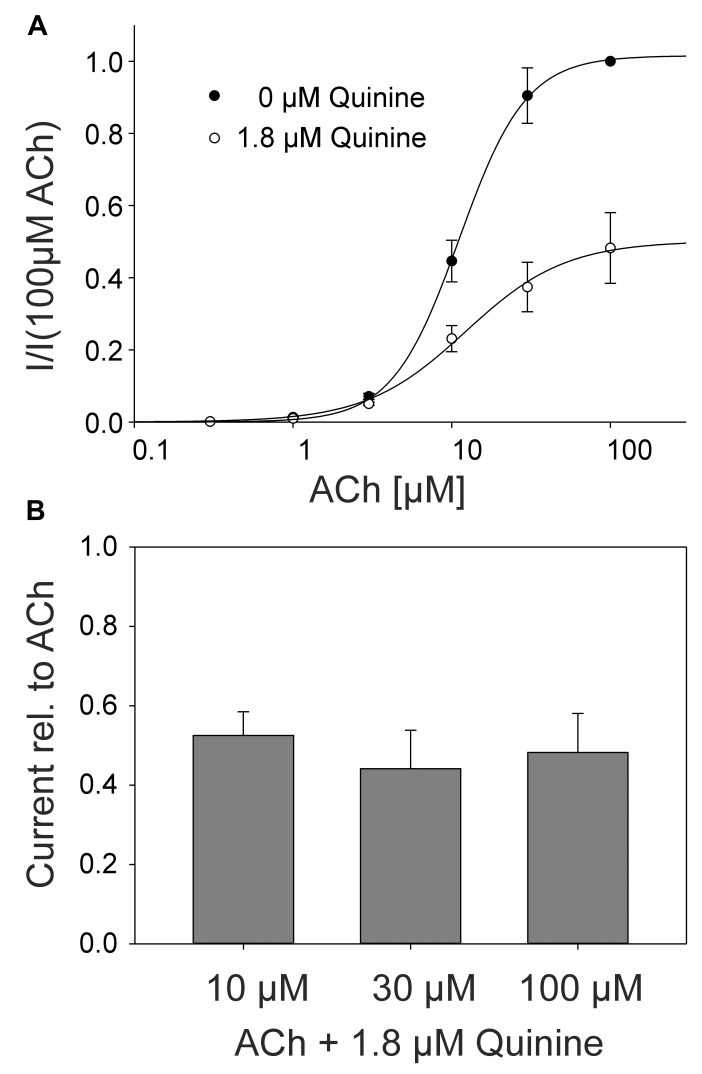

FIGURE 4 | ACh concentration-response relationship at human adult muscle nAChRs in the presence and absence of $1.8 \mu \mathrm{M}$ quinine measured in Xenopus oocytes. Currents were elicited by various ACh concentrations. (A) Concentration-response curves for human adult muscle nAChRs in the presence (open circles) and the absence (filled circles) of $1.8 \mu \mathrm{M}$ quinine $(n=6)$. (B) Relative current blocked by $1.8 \mu \mathrm{M}$ quinine at 10,30 , and $100 \mu \mathrm{M}$ ACh. Holding potential: $-60 \mathrm{mV}$, error bars represent S.E.M.

(Schreiner et al., 2014). We tested the modulatory effects of quinine on the response evoked by $100 \mu \mathrm{M}$ ACh, a near $\mathrm{EC}_{50}$ value of the agonist, which blocked the ACh-evoked currents in a dose-dependent manner with an $\mathrm{IC}_{50}$ of $12.8 \pm 1.3 \mu \mathrm{M}$ $(n=3)$ (Supplementary Figure 1B). The neuronal $\alpha 7$ subtype is of significantly lower potency compared to the muscular type $(p<0.0001)$.

\section{DISCUSSION}

This study describes the effects of quinine, quinidine, and chloroquine on human muscle nAChRs. All three compounds are potent antagonists which block in the low $\mu$-molar range $\left(\mathrm{IC}_{50} \sim 1.7-4 \mu \mathrm{M}\right)$ which corresponds to a concentration of $0.6-1.4 \mathrm{mg} / \mathrm{l}$ quinine sulfate. Compared with the reported potency at other receptors, quinine shows a similar potency at the neuronal rat $\alpha 9 \alpha 10 \mathrm{nAChRs}\left(\mathrm{IC}_{50} \sim 1 \mu \mathrm{M}\right)$ and the human homomeric $5 \mathrm{HT} 3_{\mathrm{A}}$-receptors $\left(\mathrm{IC}_{50} \sim 1 \mu \mathrm{M}\right)$, but is less potent at the human neuronal $\alpha 7 \mathrm{nAChR}\left(\mathrm{IC}_{50} \sim 13 \mu \mathrm{M}\right)$, the human
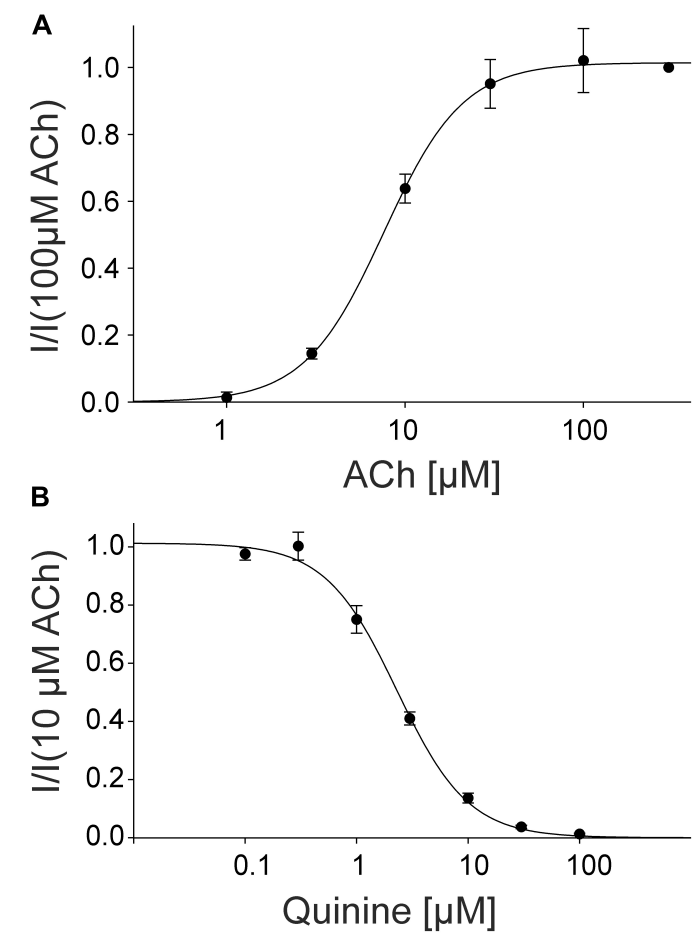

FIGURE 5 | Concentration-dependent activating effect of ACh on the fetal human nicotinic acetylcholine receptor $\alpha \beta \gamma \delta$ measured in Xenopus oocytes. (A) Concentration-response curve of the receptor activated by different concentrations of acetylcholine $(n=6)$. (B) Block of human fetal muscle $n A C h R s$ by quinidine in a concentration-dependent manner.

Concentration-inhibition curves for quinine (circles) at ACh mediated currents elicited by $10 \mu \mathrm{M}$ ACh in the presence of different concentrations of the blocker $(n=3)$. Holding potential: $-60 \mathrm{mV}$, error bars represent S.E.M.

heteromeric $5 \mathrm{HT} \mathrm{AB}^{-}\left(\mathrm{IC}_{50} \sim 16 \mu \mathrm{M}\right)$ or human $\mathrm{GABA}(\mathrm{A})$ receptors ( $\mathrm{IC}_{50} \sim 1.6 \mathrm{mM}$ ) (Ballestero et al., 2005; Thompson and Lummis, 2008). At a similar low $\mu \mathrm{M}$ concentration range the interference with the neuromuscular transmission (Sieb et al., 1996) or the decrease in the open duration of muscle nAChRs (Fukudome et al., 1998b) was observed for quinoline derivatives in vitro.

At human muscle nAChRs receptors the observed quinine block was consistent with a non-competitive antagonism. These mode of antagonism for quinine was also reported at human heteromeric 5-HT3 ${ }_{\mathrm{AB}}$-receptors (Thompson and Lummis, 2008). At rat neuronal $\alpha 9 \alpha 10 \mathrm{nAChRs}$, quinine was proposed to block competitively at lower, however, non-competitively at higher concentrations (Ballestero et al., 2005). We observed a voltagedependency for the quinine block of the muscular AChR similar to that reported for the rat $\alpha 9 \alpha 10 \mathrm{nAChR}$. Our results indicate that quinine could interact with a charged side chain within or near the channel pore as discussed in detail for the $\alpha 9 \alpha 10 \mathrm{nAChR}$ by Ballestero et al. (2005).

Human homomeric $5-\mathrm{HT}_{\mathrm{A}}$ and $\mathrm{GABA}(\mathrm{A})$ receptors were blocked in a competitive manner (Thompson and Lummis, 2008). Binding studies at the recombinant muscle receptor expressed in HEK293 cells support the observed non-competitive 
antagonism of quinine, as even concentrations up to $30 \mu \mathrm{M}$ of the antagonist could not inhibit the binding of $\alpha$-bungarotoxin (Sieb et al., 1996).

Regarding the high homology between $5-\mathrm{HT} 3_{\mathrm{A}}, \mathrm{GABA}(\mathrm{A})$ and $\mathrm{nAChRs}$ and the similarities in the actions of quinoline compounds, conserved sites of action for these compounds were suggested (Thompson and Lummis, 2008).

For the therapy of malaria, an about ten-fold higher oral dosage of quinine is needed than against muscle cramps, and anti-malaria plasma concentrations of $10-15 \mathrm{mg} / \mathrm{l}$ are recommended. During acute malaria, quinine plasma concentrations are higher than under non-infectious conditions. Metabolic clearance of quinine in acute illness is reduced because of decreased cytochrome P450 (CYP) 3A4 activity. Increased $\alpha$-1-acid glycoprotein concentrations in the acute phases of malaria lead to an increased plasma protein binding of quinine, which contributes to the decreased volume of distribution and the increased quinine concentration during the acute phase of the disease (Kloprogge et al., 2014). Thus, the in vitro observed effects of quinine at central nervous receptors are to be expected in general above a plasma concentration of $10 \mu \mathrm{g} / \mathrm{ml}$ which is not reached after intake of 200-400 mg quinine sulfate against muscle cramps.

When quinine sulfate $2 \times 260 \mathrm{mg}$ is applied orally to humans, a dosage which lies in the range used in therapy and prophylaxis of nocturnal leg cramps, a peak plasma concentration of $2.5 \mu \mathrm{g} / \mathrm{ml}$ is reached at about $2 \mathrm{~h}$ after intake of quinine. Plasma elimination half time is about $11-12 \mathrm{~h}$; accordingly, plasma concentration was decreased to $1.6 \mu \mathrm{g} / \mathrm{ml}$ after $12 \mathrm{~h}$ (Dieterich et al., 1984). These values are in the same concentration range as measured for the inhibitory effect of quinine at the human muscle AChR; thus, this effect may be postulated as a possible mechanism of action of the muscle relaxant effect of quinine which has been therapeutically used in patients with leg cramps for more than half a century.

In summary, we have shown that the quinine, quinidine and chloroquine antagonize ACh-evoked responses at muscular nAChRs. The potency for quinine at the muscle nAChRs was in the same range as found for neuronal rat $\alpha 9 \alpha 10 \mathrm{AChR}$ or

\section{REFERENCES}

Albuquerque, E. X., Pereira, E. F., Alkondon, M., and Rogers, S. W. (2009). Mammalian nicotinic acetylcholine receptors: from structure to function. Physiol. Rev. 89, 73-120. doi: 10.1152/physrev.00015. 2008

Ballestero, J. A., Plazas, P. V., Kracun, S., Gómez-Casati, M. E., Taranda, J., Rothlin, C. V., et al. (2005). Effects of quinine, quinidine, and chloroquine on alpha9alpha10 nicotinic cholinergic receptors. Mol. Pharmacol. 68, 822-829. doi: 10.1124/mol.105.014431

Bleecker, J. L., de Meire, V. I., and Pappens, S. (1998). Quinidine prevents paraoxon-induced necrotizing myopathy in rats. Neurotoxicology, 19, 833-838.

Diener, H. C., Dethlefsen, U., Dethlefsen-Gruber, S., and Verbeek, P. (2002). Effectiveness of quinine in treating muscle cramps: a double-blind, placebocontrolled, parallel-group, multicentre trial. Int. J. Clin. Pract. 56, 243-246.

Dieterich, H. A., Messer, W., and Jaehnchen, E. (1984). Plasma concentrations of theophylline and quinine in healthy volunteers following oral administration of a fixed drug combination. Arzneimittelforschung 34, 520-522. human 5-HT3 ${ }_{\mathrm{A}}$-receptors (Ballestero et al., 2005; Thompson and Lummis, 2008). However, quinine was slightly less potent at the neuronal human $\alpha 7 \mathrm{AChR}$.

Typical blood and tissue concentrations for quinine indicate possible action on muscle nAChRs. These observations further extend the pharmacological knowledge on receptors affected by quinoline derivatives. The reversible inhibitory effect of quinine on human muscle nAChRs may be one mechanism which contributes to the clinically proven efficacy of quinine against leg cramps. But as quinine is a wide spectrum channel blocker, further research on its interaction with receptors of different type and location would be of interest.

\section{AUTHOR CONTRIBUTIONS}

HH, GG, and BW-J conceived and designed the experiments. DA performed the experiments. DA and GG analyzed the data. GG and BW-J wrote the paper.

\section{FUNDING}

The authors acknowledge support by the Open Access Publication Funds of the Ruhr-Universität Bochum. The funders had no role in study design, data collection and analysis, decision to publish, or preparation of the manuscript.

\section{ACKNOWLEDGMENTS}

We thank T. Lichtleitner and U. Müller for the excellent technical assistance.

\section{SUPPLEMENTARY MATERIAL}

The Supplementary Material for this article can be found online at: https://www.frontiersin.org/articles/10.3389/fphar. 2018.01339/full\#supplementary-material

El-Tawil, S., Al Musa, T., Valli, H., Lunn, M. P. T., Brassington, R., El-Tawil, T., et al. (2015). Quinine for muscle cramps. Cochrane Database Syst. Rev. 8:CD005044. doi: 10.1002/14651858.CD005044.pub3

Engel, A. G. (2018). Genetic basis and phenotypic features of congenital myasthenic syndromes. Handb. Clin. Neurol. 148, 565-589. doi: 10.1016/B978-0-44464076-5.00037-5

Fukudome, T., Ohno, K., Brengman, J. M., and Engel, A. G. (1998a). AChR channel blockade by quinidine sulfate reduces channel open duration in the slowchannel congenital myasthenic syndrome. Ann. N. Y. Acad. Sci. 841, 199-202. doi: 10.1111/j.1749-6632.1998.tb10928.x

Fukudome, T., Ohno, K., Brengman, J. M., and Engel, A. G. (1998b). Quinidine normalizes the open duration of slow-channel mutants of the acetylcholine receptor. Neuroreport 9, 1907-1911.

Garland, C. M., Foreman, R. C., Chad, J. E., Holden-Dye, L., and Walker, R. J. (1998). The actions of muscle relaxants at nicotinic acetylcholine receptor isoforms. Eur. J. Pharmacol 357, 83-92. doi: 10.1016/S0014-2999(98)00542-1

Gisselmann, G., Plonka, J., Pusch, H., and Hatt, H. (2004). Unusual functional properties of homo- and heteromultimeric histamine-gated chloride channels 
of Drosophila melanogaster: spontaneous currents and dual gating by GABA and histamine. Neurosci. Lett. 372, 151-156. doi: 10.1016/j.neulet.2004. 09.031

Glavinović, M. I., and Trifaró, J. M. (1988). Quinine blockade of currents through Ca2+-activated $\mathrm{K}+$ channels in bovine chromaffin cells. J. Physiol. 399, 139-152. doi: 10.1113/jphysiol.1988.sp017072

Harper, C. M., and Engel, A. G. (1998). Quinidine sulfate therapy for the slowchannel congenital myasthenic syndrome. Ann. Neurol. 43, 480-484. doi: 10. 1002/ana.410430411

Harper, C. M., Fukodome, T., and Engel, A. G. (2003). Treatment of slow-channel congenital myasthenic syndrome with fluoxetine. Neurology 60, 1710-1713. doi: 10.1212/01.WNL.0000061483.11417.1B

Imai, S., Suzuki, T., Sato, K., and Tokimasa, T. (1999). Effects of quinine on three different types of potassium currents in bullfrog sympathetic neurons. Neurosci. Lett. 275, 121-124. doi: 10.1016/S0304-3940(99)00 $775-2$

Jonsson Fagerlund, M., Dabrowski, M., and Eriksson, L. I. (2009). Pharmacological characteristics of the inhibition of nondepolarizing neuromuscular blocking agents at human adult muscle nicotinic acetylcholine receptor. Anesthesiology 110, 1244-1252. doi: 10.1097/ALN.0b013e31819fade3

Kalamida, D., Poulas, K., Avramopoulou, V., Fostieri, E., Lagoumintzis, G., Lazaridis, K., et al. (2007). Muscle and neuronal nicotinic acetylcholine receptors. Structure, function and pathogenicity. FEBS J. 274, 3799-3845. doi: $10.1111 /$ j.1742-4658.2007.05935.x

Katzberg, H. D. (2015). Neurogenic muscle cramps. J. Neurol. 262, 1814-1821. doi: 10.1007/s00415-015-7659-x

Kloprogge, F., Jullien, V., Piola, P., Dhorda, M., Muwanga, S., Nosten, F., et al. (2014). Population pharmacokinetics of quinine in pregnant women with uncomplicated Plasmodium falciparum malaria in uganda. J. Antimicrob. Chemother. 69, 3033-3040. doi: 10.1093/jac/dku228

Ohno, K., Wang, H. L., Milone, M., Bren, N., Brengman, J. M., Nakano, S., et al. (1996). Congenital myasthenic syndrome caused by decreased agonist binding affinity due to a mutation in the acetylcholine receptor epsilon subunit. Neuron 17, 157-170. doi: 10.1016/S0896-6273(00)80289-5

Peyer, A.-K., Abicht, A., Heinimann, K., Sinnreich, M., and Fischer, D. (2013). Quinine sulfate as a therapeutic option in a patient with slow channel congenital myasthenic syndrome. Neuromuscul. Disord. 23, 571-574. doi: 10.1016/j.nmd. 2013.04.001
Schreiner, B. S., Lehmann, R., Thiel, U., Ziemba, P. M., Beltrán, L. R., Sherkheli, M. A., et al. (2014). Direct action and modulating effect of (+)- and (-)-nicotine on ion channels expressed in trigeminal sensory neurons. Eur. J. Pharmacol. 728, 48-58. doi: 10.1016/j.ejphar.2014.01.060

Sergeeva, O. A., Kletke, O., Kragler, A., Poppek, A., Fleischer, W., Schubring, S. R., et al. (2010). Fragrant dioxane derivatives identify betal-subunit-containing GABAA receptors. J. Biol. Chem. 285, 23985-23993. doi: 10.1074/jbc.M110. 103309

Sieb, J. P., Milone, M., and Engel, A. G. (1996). Effects of the quinoline derivatives quinine, quinidine, and chloroquine on neuromuscular transmission. Brain Res. 712, 179-189. doi: 10.1016/0006-8993(95)01349-0

Silamut, K., White, N. J., Looareesuwan, S., and Warrell, D. A. (1985). Binding of quinine to plasma proteins in falciparum malaria. Am. J. Trop. Med. Hyg. 34, 681-686. doi: 10.4269/ajtmh.1985.34.681

Thompson, A. J., Lochner, M., and Lummis, S. C. (2007). The antimalarial drugs quinine, chloroquine and mefloquine are antagonists at 5-HT3 receptors. $\mathrm{Br}$. J. Pharmacol. 151, 666-677. doi: 10.1038/sj.bjp.0707238

Thompson, A. J., and Lummis, S. C. R. (2008). Antimalarial drugs inhibit human 5-HT(3) and GABA(A) but not GABA(C) receptors. Br. J. Pharmacol. 153, 1686-1696. doi: 10.1038/bjp.2008.34

Upadhyaya, J. D., Chakraborty, R., Shaik, F. A., Jaggupilli, A., Bhullar, R. P., and Chelikani, P. (2016). The pharmacochaperone activity of quinine on bitter taste receptors. PLoS One 11:e0156347. doi: 10.1371/journal.pone.0156347

Conflict of Interest Statement: BW-J was employed by company Cassella-med $\mathrm{GmbH} \& \mathrm{Co}$.

The remaining authors declare that the research was conducted in the absence of any commercial or financial relationships that could be construed as a potential conflict of interest.

Copyright (C) 2018 Gisselmann, Alisch, Welbers-Joop and Hatt. This is an open-access article distributed under the terms of the Creative Commons Attribution License (CC BY). The use, distribution or reproduction in other forums is permitted, provided the original author(s) and the copyright owner(s) are credited and that the original publication in this journal is cited, in accordance with accepted academic practice. No use, distribution or reproduction is permitted which does not comply with these terms. 